\title{
Are We the Walking Dead? Burnout as Zombie Apocalypse
}

\author{
Benjamin R. Doolittle, MD, MDiv
}

Internal Medicine \& Pediatrics, Combined Internal Medicine \& Pediatrics Residency Program, Department of Internal Medicine, Yale University, New Haven, Connecticut

\begin{abstract}
The Walking Dead, one of the most popular television shows in recent history, uses the plot of a zombie apocalypse as a lens into exploring the human condition. Amidst a particularly dangerous moment, the show's hero references the human struggle to survive by remarking, "We are the walking dead." This offhand comment sheds light upon physicians' struggles in medicine, in particular the high prevalence of burnout and the challenge to cultivate compassion and meaning. This is an important question for our age and for our profession. Are we the walking dead?
\end{abstract}

Ann Fam Med 2016;14:578-580. doi: 10.1370/afm.1975.

$\mathrm{I}$ $\mathrm{t}$ is the zombie apocalypse, sometime in the near future. The band of survivors - a remnant of humankind - hides out in a ramshackle barn. Outside, a zombie herd swarms towards them. Rick Grimes, the tortured, morally conflicted hero, gathers his exhausted, dispirited tribe. He says, "We must do what we must to survive.... We are the walking dead."

In a dark corner, Darryl, the redeemed bad-boy with the cross-bow quips, "No. We ain't them." We are not zombies.

And so continues my fascination with The Walking Dead, one of the most popular TV shows in recent history. I became captivated with zombies during the summer of 2013. As we "binge-watched" (when did that become a word?) the seasons, my 12 year old daughter and I got caught up in the ghoulish story line, the slasher scenes, and the over-the-top zombie craziness.

Surprisingly, we began debating the complicated ethical challenges the characters face. Is it right for Rick to leave his family to rescue a scoundrel handcuffed to a rooftop pipe? What does it take to belong to a new group? And what do you need to live authentically, to find true happiness, when society has collapsed and moral anchors no longer exist? These are complicated questions; and the show became the starting point between a middleaged dad and his tween daughter about society, ethics, and human nature.

I realize now that The Walking Dead only uses zombies as a backdrop to explore the human condition. Could the zombie apocalypse metaphor shed light on the state of medicine in 2016? Are we physicians the walking dead? Burnout in our profession is high-affecting on average $54 \%$ of physicians in general, and is even higher among some other specialties. Only $40 \%$ of physicians are satisfied with their work-life balance. This is worse than the general population, even when controlling for salary, hours worked, and other demographics. ${ }^{1}$ Only $54 \%$ of physicians would choose medicine again. ${ }^{2}$ Life has become filled with hassles: the numbing interface with the EMR, annoying requirements from the hospital, the insurance companies, and maintenance of certification. Like the gang in the barn, we are harried, stressed out, and traumatized. Amidst it all, we treat patients. I worry that physicians have become the walking dead, that we are living the proverbial zombie apocalypse. I fear that the separation between the dead and the living, the zombie and the physician is a matter not of kind

but of degree. We have become what we fear.
Benjamin R. Doolittle, MD, MDiv Combined Internal Medicine \& Pediatrics Residency Program Department of Internal Medicine PO Box 8030

New Haven, CT 06520-8030

Benjamin.doolittle@yale.edu 


\section{THE WALKING DEAD}

The show takes place in the southern United States. A mysterious virus has infected humans such that when we die, we turn into the undead. Zombies wander across the country, consuming flesh, unresponsive to pain. The scent of the living makes them crazy with hunger. Rick Grimes, a former police officer, is a magnet for a motley bunch of humans: a woman who suffered spousal abuse turned pragmatic murderer, a meth head who found leadership and belonging, a swordwielding woman who disarmed (literally) her boyfriend and brother and used them as pack-zombies.

I had always assumed that the title The Walking Dead referred to the zombies. And yet, shockingly, Rick Grimes is on to something-we bumans are the walking dead.

The show comments on the nature of human beings: we are weird and dangerous, prone to self-interest, and not far from our base animal instincts. A zombie staggers about, numb to the world, decomposing, not quite dead, but not truly living. Does that describe the physician staring bleary-eyed at the computer screen, callous to the needs of patients, disoriented by the workload, late for dinner yet again? I wonder if we are frightened of zombies, not because they are so different from us, but because they are so much like us.

\section{QUIET LIBERATION}

After hearing Dr Arthur Kleinman give a recent lecture, I sought out his book What Really Matters - Living a Moral Life Amidst Uncertainty and Danger. ${ }^{3}$ If ever there was a book about navigating the zombie apocalypse, this is it. Dr Kleinman has had a storied career as both a psychiatrist and anthropologist at Harvard. He writes in his book, "I don't see any convincing evidence that facing up to our human condition leads to paralysis and pathology. Quite the opposite... Seeing the world as dangerous and uncertain may lead to a kind of quiet liberation, preparing us for new ways of being ourselves, living in the world, and making a difference in the lives of others. Surprisingly, confronting the deepest fears can mean giving them up and asking critically why we ever allowed ourselves to be so morally and emotionally shackled." ${ }^{\prime \prime(p ~ 10)}$

I find Kleinman's perspective liberating. There is much change that needs to be made in medicine; we are still in the dark ages with EMR 1.0, we still struggle with burnout, insurance companies, challenging patients, etc. But I appreciate that facing it all leads to a "quiet liberation." Unfortunately, simply "facing up" to the apocalypse (zombie, EMR, or otherwise) is not enough. A recent serendipitous rediscovery that helps me understand this "quiet liberation" is Viktor
Frank1. Dr Frankl, another psychiatrist, practiced in Vienna during the 1930s. Because he was Jewish, soon after the Nazis invaded Austria, he was deported to the concentration camps and worked as a slave-laborer in Auschwitz and Dachau. He had everything taken away. He was separated from his family, stripped of his professional identity. The Nazis shaved his head and tattooed a number on his arm. He was regularly beaten, starved, and forced to do hard labor.

His book, Man's Search for Meaning, describes his experiences and offers how he coped with such unbearable suffering. ${ }^{4} \mathrm{He}$ describes how fellow inmates would perish not necessarily from disease or lack of food, but from lack of hope. Dr Frankl describes how the light in bunkmate's eyes would grow dim and the next day he would die.

Dr Frankl believed that if we could maintain some sense of purpose to our lives, we would be more likely to survive. To Frankl, purpose was a choice. He writes, "We who lived in concentration camps can remember the men who walked through the huts comforting others, giving away their last piece of bread. They may have been few in number, but they offer sufficient proof that everything can be taken from a man but one thing: the last of the human freedoms-to choose one's attitude in any given set of circumstances, to choose one's own way." ${ }^{\prime \prime(p 86)}$ Frankl believed that the meaning to life was not the surrogates of pleasure, wealth, or prestige. The real meaning to life is to claim a purpose- to reach out, to care, to serve. In the concentration camps, to choose is to live. To live is to choose a purpose. Sometimes that purpose is a life goal. Sometimes that purpose is just to survive the day. Viktor Frankl was condemned to a concentration camp, but he did not condemn himself to darkness. He claimed the freedom to choose life amidst so much death, to seek love amidst cold despair.

\section{PHYSICIANS, NOT ZOMBIES}

What does it look like for a physician in 2016 to apply the principles of Kleinman and Frankl? While there is great need for systematic change, I'm not sure if a better EMR, smoother relations with our hospitals, less complicated MOC requirements, and nicer patients will make much of a difference. And yet, something must be done. Burnout and wellness have become trendy topics these days. But there is little to suggest that mindfulness courses, yoga-at-lunch, or work hour changes have made much difference.

I believe that Kleinman and Frankl have much to teach us and so does Rick and his motley gang. What separates the zombie from the living, is not appetite or suffering, it is our "quiet liberation," our purpose. 
Frankl references Nietzsche, who said, "Those who have a 'why' to live, can bear almost any 'how.'" 4(p 126) I believe that reclaiming this central purpose, holding this "why" as a core belief, is critical to physician wellbeing. Rick and his gang have a clear purpose, a clear "why:" to survive, to promote life. This could be our core principle: to promote life, to focus on the healing of our patients and even the flourishing of our own lives. Holding fast to a core principle amidst all the stressors of our jobs is no small task, but it might be the most important thing we do. I believe this takes courage and character. Life is hard in the apocalypse; and there are no easy answers. It might cost us our salaries and some RVU's if it means slowing down. For Frankl, it was the difference between life and death. I believe this is true for physicians as well. No amount of work-life rebalancing, mindfulness exercises, or personal coaching will ameliorate burnout without this. We, as physicians, need to figure this out, for each of us, for our patients. The apocalypse is upon us. Are we the walking dead? We will soon find out.
To read or post commentaries in response to this article, see it online at http://www.annfammed.org/content/14/6/578.

Key words: burnout; coping; meaning; purpose; professionalism; Frankl; Kleinmann; zombie

Submitted December 2, 2015; submitted, revised, May 6, 2016; accepted May 31, 2016.

\section{References}

1. Shanafelt, Tait D, et al. Changes in burnout and satisfaction with work-life balance in physicians and the general US working population between 2011 and 2014. Mayo Clinic Proceedings, 2015(90):12; 1600-1613.

2. Adams, S. Why do so many doctors regret their job choice. Forbes. http://www.forbes.com/sites/susanadams/2012/04/27/why-do-somany-doctors-regret-their-job-choice/. Accessed Oct 12, 2015.

3. Kleinman A. What Really Matters: Living a Moral Life Amidst Uncertainty and Danger. Oxford, UK: Oxford University Press; 2006.

4. Frankl VE. Man's Search for Meaning. New York, NY: Simon and Schuster; 1985.

\section{CHANGE-OF-ADDRESS FORM \\ FAMILY MEDICINE}

Please complete this form and mail to the following address or fax to Annals Circulation at 913-906-6080:

Annals of Family Medicine, Circulation Department, 11400 Tomahawk Creek Pkwy, Leawood, KS 66211-2680

Check if member of sponsoring organization:

$$
\begin{array}{ll}
\square \text { AAFP } \square \text { ABFM } \square \text { STFM } \square \text { ADFM } \\
\square \text { AFMRD } \square \text { NAPCRG } \square \text { CFPC }
\end{array}
$$

ID number from label on your journal cover

OLD Information (Please print.)

\begin{tabular}{ll}
\hline Name \\
\hline Company (if applicable) \\
\hline Address (Street plus Apt or Ste) \\
\hline City & Postal Code (9-digit ZIP for US) \\
\hline Country & Fax \\
\hline Telephone & \\
\hline E-Mail &
\end{tabular}

NEW Information (Please print.)

\begin{tabular}{ll}
\hline Name \\
\hline Company (if applicable) \\
\hline Address (Street plus Apt or Ste) \\
\hline City \\
\hline Country \\
\hline Telephone \\
\hline E-Mail
\end{tabular}

